\title{
PATHOPHYSIOLOGICAL EFFECT OF CHRONIC AND ACUTE STRESS IN ATLANTIC SALMON, SALMO SALAR (ACTINOPTERYGII: SALMONIFORMES: SALMONIDAE)
}

\author{
Armin KOUSHA $^{1 *}$, Reidar MYKLEBUST ${ }^{2}$, and Rolf Erik OLSEN ${ }^{3}$ \\ ${ }^{1}$ Norwegian College of Fishery Science, Faculty of Biosciences, Fisheries, and Economics, \\ The Arctic University of Norway, 9037 Tromsø, Norway \\ ${ }^{2}$ Molecular and Imaging Center (MIC), University of Bergen, Norway \\ ${ }^{3}$ Institute of Marine Research, Matre Aquaculture Research Station, Matredal, Norway
}

\begin{abstract}
Kousha A., Myklebust R., Olsen R.E. 2013. Pathophysiological effect of chronic and acute stress in Atlantic salmon, Salmo salar (Actinopterygii: Salmoniformes: Salmonidae). Acta Ichthyol. Piscat. 43 (4): 299-305.
\end{abstract}

\begin{abstract}
The knowledge on the effect of different stress factors on Atlantic salmon, Salmo salar Linnaeus, 1758 , is far from complete and therefore we decided to find out how the low water level stress could effect pathophysiological parameters such as: plasma cortisol level, haemoglobin, haematocrit, chloride $\left(\mathrm{Cl}^{-}\right)$, sodium $\left(\mathrm{Na}^{+}\right)$, osmolality, lactate, and glucose in this fish; and how this stressor affects the gut morphology. Two hundred and four juvenile Atlantic salmon were randomly distributed into six fibreglass tanks and divided into two groups: group 1 (control) and group 2 (low water level stress). The low water level stress did not affect growth performance and the pathophysiological parameters. Light- and transmission electron microscopy evaluations of the pyloric caeca and the distal intestine revealed that chronic stress had no effect on gut morphology. Low water level stress had no clear effects on pathophysiological parameters and gut morphology of Atlantic salmon.
\end{abstract}

Keywords: chronic and acute stress, Atlantic salmon, haematological parameters, gut, light microscopy, transmission electron microscopy

It is well known that fish are exposed to stressors in the wild as well as in captivity, particularly during handling in commercial aquaculture. Numerous papers have reported that chronic and acute stress may be associated with biochemical and physical disturbances and various physiological effects (Kubilay and Uluköy 2002, Vijayan et al. 2009). Plasma cortisol is reported to increase in fish after stress exposure and this is well documented in several studies (Barton et al. 1988, Mustafa and MacKinnon 1999, Olsen et al. 2002, 2005, 2008, Askarian and Kousha 2009, Santos et al. 2010). Cortisol can also affect growth and metabolism of fish during chronic and acute stress (Fast et al. 2008, Vijayan et al. 2009).

Fridell et al. (2007) reported increased cortisol level during chronic stress response in the hyperoxic group (reduced water flow) of Atlantic salmon, Salmo salar Linnaeus, 1758, reared in freshwater. In juvenile rainbow trout, Oncorhynchus mykiss (Walbaum, 1792), the level of cortisol increased during acute stress, but after $1 \mathrm{~h}$ it regained its normal level (Fast et al. 2008, MartínezPorchas et al. 2009).

Olsen et al. (2008) subjected Atlantic cod, Gadus morhua Linnaeus, 1758, to an acute stress (exhaustive exercise) and this caused an increase in blood haematocrit and plasma cortisol, glucose, chloride, osmolality, and lactate. Other studies have reported that acute stress, inflicted by high fish densities, induced a significant increase in glucose and lactate in netted European seabass, Dicentrarchus labrax (Linnaeus, 1758) (see Santos et al. 2010) and elevating level of plasma cortisol and lactate in Atlantic salmon exposed to the infectious anaemia (Olsen et al. 1992) and acute stress response in Atlantic cod (Olsen et al. 2008). The first aim of the presently reported study was to evaluate whether lowering the water level affects the growth performance and the pathophysiological parameters of salmon. Information is available of the effect of noise on growth performance, smelting rates, parasite effects, and disease resistance (Terhune et al. 1990, Mustafa and MacKinnon 1999, Wysocki et al. 2007, Davidson et al. 2009), but to our knowledge no paper on the effect of low water stress on gut morphology has been published.

Morphological evaluations of the gastrointestinal tract by light microscopy (LM) and transmission electron microscopy (TEM) have been suggested to be an important tool to evaluate when fish are exposed to stress

\footnotetext{
${ }^{*}$ Correspondence: Armin Kousha, Fakultet for biovitenskap, fiskeri og økonomi, UiT Norges arktiske universitet, 9037, Tromsø, Norway, phone: (+47) 91008263, e-mail: arminkousha@gmail.com.
} 
(Olsen et al. 2002). In three previous studies, Olsen et al. (2002, 2005, 2008) focused on the effect of stress response on intestinal lining of Atlantic salmon, intestinal function of rainbow trout, and in fed- and food deprived Atlantic cod, Gadus morhua. According to these studies, acute stress had marginal effect on gut morphology, junctional complexes damage (zone between epithelial cells), and increased cellular detachment in Atlantic salmon and rainbow trout. The second aim of the presently reported study was therefore to address the effect of low water stress on morphological changes in pyloric caeca and distal intestine of Atlantic salmon.

The experiment started in January 2011 and lasted until May 2011 - for a total of 65 days. Juveniles of Atlantic salmon, Salmo salar, from a single population were obtained from the Institute of Marine Research, Matre Research Station, Matredal, Norway. Two hundred and four fish were randomly distributed into 6 fibreglass tanks, 34 fish per tank, with a total average wet weight of approximately $7 \mathrm{~kg}$ per tank. The 400 -L tanks were supplied with sea water (temperature $8-10^{\circ} \mathrm{C}$, water flow $\left.20 \mathrm{~L} \cdot \mathrm{min}^{-1}\right)$. The fish were acclimatized to experimental conditions for two days prior to the experiment. The individual fish weight (mean \pm standard deviation) ranged from $104 \pm 4.9$ to $354 \pm 6.1 \mathrm{~g}$ while individual fork length (mean \pm standard deviation) ranged from $220 \pm 1.5$ to $300 \pm 1.6 \mathrm{~mm}$. The fish were divided into two groups: group 1 (control) and group 2 (low water level stress). The experiments (in two groups) were carried out in triplicate for 65 days. During that time the fish were fed Fiskefor pellets (Skretting Ltd., $50 \mathrm{mg}, 3 \mathrm{~mm}$ ) at $1000 \mathrm{~h}$ and $1400 \mathrm{~h}$; $2.5 \%$ of wet body weight per day. Faeces and uneaten food in the tanks were collected $1 \mathrm{~h}$ after each feeding.

Cleaning of rearing tanks is a normal procedure in commercial aquaculture and this chronic stress may affect the fish. In order to evaluate how fish react to this stress; the water level in three tanks were lowered (reduced to $10 \mathrm{~cm}$ ) for $30 \mathrm{~min}$ twice a day at $0900 \mathrm{~h}$ and $1300 \mathrm{~h}$ throughout the 65 days. After 65 days of rearing, all the groups were exposed to low water level for $30 \mathrm{~min}$ (acute stress).

Specific growth rate (SGR) and feed conversion ratio (FCR) were calculated using the formulae described by De Silva and Anderson (1995) as follows:

$$
\mathrm{SGR}=100\left[\ln W_{\mathrm{f}}-\ln W_{\mathrm{i}}\right] \cdot t^{-1}
$$

where: $W_{\mathrm{i}}$ and $W_{\mathrm{f}}$ were the initial and final body weight $[\mathrm{g}]$ and $t$, the time in days.

$$
\mathrm{FCR}=\mathrm{FC} \cdot \mathrm{WG}^{-1}
$$

where: $\mathrm{WG}=$ wet weight gain, $\mathrm{FC}=$ dry feed consumed [g].

Fish sampled for blood analysis were anesthetized using tricaine methanesulfonate (MS-222), 70 ppm for 3 min, to avoid bleeding stress. Blood samples from 30 fish of each treatment were taken from the caudal artery using commercially produced heparinised needles.

Haematocrit was measured using heparinised microcapillary tubes and a Compur M1100 haematocrit centrifuge according to Olsen et al. (2002, 2008). Blood $(100 \mu \mathrm{L})$ were transferred to a $0.5 \mathrm{~mL}$ Eppendorf tubes and frozen in liquid nitrogen and further stored at $-80^{\circ} \mathrm{C}$ prior to analysis of haemoglobin, which was estimated using the ReflotronPlus auto analyzer (Roche, Mannheim, Germany) according to Olsen et al. (2008). Blood osmolality was measured using freeze point determination (Advanced Micro Osmometer Model 3300, Advanced Instruments Inc., Norwood, MA, USA). Plasma was prepared from the remaining blood sample by immediate centrifugation at $11000 \mathrm{rpm}$ for $1 \mathrm{~min}$ (Jouan A14), frozen in liquid nitrogen and stored at $-80^{\circ} \mathrm{C}$ until analyzed. Plasma chloride concentrations $\left(\mathrm{Cl}^{-}\right)$, lactate, $\mathrm{Na}^{+}$ and $\mathrm{K}^{+}$were analysed by ion-selective electrode (Cobas C.111). Plasma cortisol was measured by ELISA as described by Barry et al. (2001).

Fish used for analysing biochemical parameters were also used for LM and TEM evaluations of the gut. Abdomens were carefully opened aseptically and samples from pyloric caeca and distal intestine were immediately fixed in formalin and Karnovsky fixative as described by Olsen et al. (2002). To determine morphological differences of the various treatments, 10 randomly selected LM and TEM images from each segment were sampled from five fish of each treatment group.

The morphological changes were evaluated in the terms of full and empty goblet cells, length of microvilli $[\mu \mathrm{m}]$, disintegrated microvilli, number of vacuoles, oedema and cell damage, and number of granulocytes in lamina propria. Differences were ranked according to Ringø et al. (2007b); $0=$ no observed, $1=$ low ( $1-3$ out of 10 images), $2=$ moderate ( $4-6$ out of 10 images $), 3=$ high $(7$ or more out of 10 images).

Statistical analyses of the results were performed using MS Excel software. Numerical results were exhibited as the mean \pm standard deviation. The Pearson's product-moment correlation coefficient was calculated and tested for significance against the no correlation zero hypothesis through the procedure correlation. Data performed to analysis of variance (ANOVA) test to observed variance in a particular variable. The significance level was chosen at $P<0.05$. Normality and variance homogeneity of data were carried out by using Norm-Quant software and $F$-test in MS Excel, respectively. Student's $t$-test was run as post hoc test when ANOVA was valid for data set.

The experiment was approved by the Food Safety Authority, FOTS, Norway (No. 2907: Etablering av kronisk stressmodell).

Throughout the experiment no mortalities were observed. The presently reported study showed that stress had not significantly affected growth during the experiment; 65 days (Table 1). The specific growth rates (SGR) ranged between 0.95 and 0.97 , feed conversion ratios (FCR) ranged from 0.46 to 0.54 , and weight gains were between 6050 and $6277 \mathrm{~g}$.

Results of blood cortisol sampled from the control group (not exposed to stress; 65 days) and after chronic stress and acute stress are presented in Table 2. The results of blood cortisol level $\left(\mathrm{ng} \cdot \mathrm{mL}^{-1}\right)$ of the two treatment groups: control (group 1), and low water level stress (group 2) showed no significant differences $(P>0.05)$. Table 3 display the 
results of haematocrit, haemoglobin, glucose, lactate, $\mathrm{K}$, $\mathrm{Na}, \mathrm{Cl}$, and osmolality and show that these parameters were not affected by the different treatments.

Morphological evaluations of pyloric caeca and distal intestine of the control group and group 2 exposed to chronic stress are shown in Table 4. No clear differences with regard to full and empty goblet cells, number of vacuoles and granulocytes within lamina propria were observed. Mean length of microvilli in pyloric caeca; estimated by light microscopy, were shorter but not significantly different; in the control group; $3.9 \pm 0.59 \mu \mathrm{m}$, compared with the low water level group; $4.6 \pm 0.75 \mu \mathrm{m}$. A similar trend was observed for the microvilli length in distal intestine being shorter in the control group compared to the other treatment groups, but the results showed no significant differences between the groups $(P>0.05)$.

Histological evaluations of pyloric caeca and distal intestine of Atlantic salmon exposed to one hour of acute stress by LM and TEM are shown in Table 5. No loosening of enterocytes from basal membrane in the treatment groups was observed (results not shown). A high score (3) of both full and empty goblet cells were noticed in group 1 (control) compare to group 2 (low water level; score 1). Disintegrated microvilli determined by TEM, but to less extent were only detected in distal intestine of the control

Table 1

Specific growth rate, feed conversion ratio, initial and final weight per treatment, and weight gain of Atlantic salmon, Salmo salar, during 65-day exposure to low water level acute stress

\begin{tabular}{lcc}
\hline Treatment & $\begin{array}{c}\text { Group 1 } \\
\text { (control) }\end{array}$ & $\begin{array}{c}\text { Group 2 } \\
\text { (low water level) }\end{array}$ \\
\hline SGR & $0.95 \pm 0.117$ & $0.97 \pm 0.079$ \\
FCR & $0.46 \pm 0.0005$ & $0.54 \pm 0.0001$ \\
Initial weight [g] & 6903.3 & 7131.3 \\
Final weight [g] & 12954 & 13408.7 \\
Weight gain [g] & 6050.7 & 6277.4 \\
\hline
\end{tabular}

Values are mean \pm standard deviation; weight gain $=$ final weight - initial weight; $n=102$ (in each treatment); $\mathrm{SGR}=$ specific growth rate, $\mathrm{FCR}=$ food conversion ratio.

Table 2

Blood cortisol levels of Atlantic salmon, Salmo salar, after 65-day exposure

to low water level acute stress and $1 \mathrm{~h}$ post-acute stress

\begin{tabular}{lcr}
\hline Parameter & \multicolumn{2}{c}{ Treatment } \\
\cline { 2 - 3 }$\left[\mathrm{ng} \cdot \mathrm{mL}^{-1}\right]$ & Group 1 & \multicolumn{1}{c}{ Group 2 } \\
\hline $\mathrm{C} 1$ & $11.01 \pm 29.01^{\mathrm{C}}$ & $12.01 \pm 3.42$ \\
$\mathrm{C} 2$ & $160.87 \pm 65.2$ & $171.33 \pm 67.2$ \\
\hline
\end{tabular}

Values are mean \pm standard deviation; Group $1=$ control, Group 2 = low water level treatment; $\mathrm{C} 1=$ blood cortisol level before acute stress, $\mathrm{C} 2$ = blood cortisol level one hour post-acute stress; $n=30$ (in each treatment); ${ }^{C_{F}}$ Fish not exposed to chronic stress. group. Some oedema or cell damages were noticed in the gastrointestinal tract of group 2, but no clear effect was noticed between the treatments. The presences of granulocytes in lamina propria in pyloric caeca and distal intestine were generally high in most of the gut segments of the treatment groups sampled one hour post acute stress except for distal intestine of group 1; estimated by TEM and group 2; estimated by LM. Mean length of microvilli estimated by LM in pyloric caeca; were shorter in the control compared to the low water level group; $5.5 \pm 1.30 \mu \mathrm{m}$ but the results showed no significant differences between the groups $(P>0.05)$.

With regard to the microvilli length the only significantly differences $(P<0.05)$ observed was between in distal intestine of group 2 (chronic stress) vs. distal intestine of group 2 (acute stress) and pyloric caeca of group 2 (chronic stress) vs. pyloric caeca of group 2 (acute stress).

LM evaluation of pyloric caeca and distal intestine of salmon exposed to chronic stress (low water level) after 65 days showed normal appearance (Fig. 1). TEM evaluations of pyloric caeca and distal intestine of this group were also normal (results not shown). TEM evaluation of distal intestine of salmon exposed to low water level stress for 65 days (Fig. 2), showed no major influence on the enterocytes of the distal intestine.

Table 3

Blood parameters of Atlantic salmon,

Salmo salar, after 65-day exposure to low water level acute stress and $1 \mathrm{~h}$ post-acute stress

\begin{tabular}{lcr} 
& \multicolumn{2}{c}{ Treatment } \\
\cline { 2 - 3 } Parameter & Group 1 & \multicolumn{1}{c}{ Group 2 } \\
\hline Hct1 $[\%]$ & $33.1 \pm 4.8^{\mathrm{C}}$ & $36.6 \pm 6.4$ \\
$\mathrm{Hct} 2[\%]$ & $9.60 \pm 2.2^{\mathrm{C}}$ & $32.5 \pm 3.6$ \\
$\mathrm{Hb} 1[\mathrm{~g} \cdot \mathrm{dL}-1]$ & $9.79 \pm 1.6$ & $8.84 \pm 0.9$ \\
$\mathrm{Hb} 2\left[\mathrm{~g} \cdot \mathrm{dL}{ }^{-1}\right]$ & $4.32 \pm 0.5^{\mathrm{C}}$ & $4.08 \pm 0.6$ \\
$\mathrm{Glu} 1\left[\mathrm{~mm} \cdot \mathrm{L}^{-1}\right]$ & $4.70 \pm 0.7$ & $4.71 \pm 0.4$ \\
$\mathrm{Glu} 2\left[\mathrm{~mm} \cdot \mathrm{L}^{-1}\right]$ & $3.41 \pm 0.7^{\mathrm{C}}$ & $3.01 \pm 0.8$ \\
$\mathrm{Lact} 1\left[\mathrm{~mm} \cdot \mathrm{L}^{-1}\right]$ & $5.52 \pm 1.8$ & $3.62 \pm 0.8$ \\
$\mathrm{Lact} 2\left[\mathrm{~mm} \cdot \mathrm{L}^{-1}\right]$ & $3.8 \pm 0.5^{\mathrm{C}}$ & $3.5 \pm 0.9$ \\
$\mathrm{~K} 1\left[\mathrm{~mm} \cdot \mathrm{L}^{-1}\right]$ & $4.3 \pm 0.5$ & $4.3 \pm 0.5$ \\
$\mathrm{~K} 2\left[\mathrm{~mm} \cdot \mathrm{L}^{-1}\right]$ & $154 \pm 2.3^{\mathrm{C}}$ & $149 \pm 8.7$ \\
$\mathrm{Na} 1\left[\mathrm{~mm} \cdot \mathrm{L}^{-1}\right]$ & $160 \pm 9.3$ & $164 \pm 3.4$ \\
$\mathrm{Na} 2\left[\mathrm{~mm} \cdot \mathrm{L}^{-1}\right]$ & $127 \pm 2.9^{\mathrm{C}}$ & $126 \pm 7.5$ \\
$\mathrm{C} 11\left[\mathrm{~mm} \cdot \mathrm{L}^{-1}\right]$ & $133 \pm 8.7$ & $140 \pm 4.5$ \\
$\mathrm{Cl} 2\left[\mathrm{~mm} \cdot \mathrm{L}^{-1}\right]$ & $329.9 \pm 7.6^{\mathrm{C}}$ & $327.8 \pm 6.1$ \\
Os $1\left[\mathrm{MOsm} \cdot \mathrm{kg}{ }^{-1}\right]$ & $355 \pm 6.3$ & $349.2 \pm 6.1$ \\
Os2 $\left[\mathrm{MOsm} \cdot \mathrm{kg}{ }^{-1}\right]$ &
\end{tabular}

Values are mean \pm standard deviation; Group $1=$ control, Group $2=$ low water level treatment; $n=30$ (in each treatment); ${ }^{\mathrm{C}}$ fish not exposed to chronic stress; Hct = haematocrit, $\mathrm{Hb}=$ haemoglobin, $\mathrm{Glu}=$ glucose, Lact = lactate, $\mathrm{K}=$ potassium, $\mathrm{Na}=$ sodium, $\mathrm{Cl}=$ chloride, $\mathrm{Os}=$ osmolality; Numbers 1 and 2 following individual parameters denote parameter level before (e.g., Hct1) and 1 h (e.g., Hctl) after acute stress. 
Histological evaluation of pyloric caeca and distal intestine of Atlantic salmon, Salmo salar, after 65 days of rearing; with no stress (control; group 1) and lowered of water level (group 2)

\begin{tabular}{lcccccccc}
\hline & \multicolumn{4}{c}{ Group 1 } & \multicolumn{3}{c}{ Group 2 } \\
\cline { 2 - 9 } Characteristics & \multicolumn{2}{c}{ Pyloric caeca } & \multicolumn{2}{c}{ Distal intestine } & \multicolumn{2}{c}{ Pyloric caeca } & \multicolumn{2}{c}{ Distal intestine } \\
\cline { 2 - 9 } & LM & TEM & LM & TEM & LM & TEM & LM & TEM \\
\hline Full goblet cells & 1 & 2 & 1 & 1 & 1 & 3 & 1 & 1 \\
Empty goblet cells & 0 & 0 & 1 & 0 & 0 & 1 & 0 & 0 \\
No. of vacuoles & 1 & 1 & 1 & 1 & 2 & 3 & 2 & 0 \\
Granulocytes in LP & 2 & 2 & 1 & 2 & 2 & 2 & 1 & 1 \\
Microvilli length & $3.9 \pm 0.59$ & - & $3.8 \pm 1.14$ & - & $4.6 \pm 0.75$ & - & $4.1 \pm 0.40$ & - \\
\hline
\end{tabular}

Group 1 = control, Group 2 = low water level treatment; $\mathrm{LM}=$ light microscopy, TEM = transmission electron microscopy; $\mathrm{LP}=$ lamina propria; Microvilli length values $[\mu \mathrm{m}]$ are mean \pm standard deviation; Scores of semi-sections for LM and TEM are based on 10 randomly taken images from each gut segment per treatment; Evaluations were ranked according to Ringø et al. (2007a): $0=$ no observed, $1=$ low ( $1-3$ out of 10 images $), 2=$ moderate $(4-6$ out of 10 images), $3=$ high $(7$ or more out of 10 images).

Histological evaluation of pyloric caeca and distal intestine of Atlantic salmon, Salmo salar,

Table 5 exposed to $1 \mathrm{~h}$ acute stress

\begin{tabular}{lcccccccc}
\hline & \multicolumn{4}{c}{ Group 1 } & \multicolumn{3}{c}{ Group 2 } \\
\cline { 2 - 9 } Characteristics & \multicolumn{2}{c}{ Pyloric caeca } & \multicolumn{2}{c}{ Distal intestine } & \multicolumn{2}{c}{ Pyloric caeca } & \multicolumn{2}{c}{ Distal intestine } \\
\cline { 2 - 9 } & LM & TEM & LM & TEM & LM & TEM & LM & TEM \\
\hline Full goblet cells & 3 & 0 & 2 & 0 & 1 & 1 & 1 & 2 \\
Empty goblet cells & 3 & 0 & 1 & 0 & 1 & 1 & 1 & 1 \\
Disint. microvilli & 0 & 0 & 0 & 1 & 0 & 0 & 0 & 0 \\
No. of vacuoles & 3 & 2 & 2 & 1 & 3 & 3 & 3 & 3 \\
OCD & 0 & 0 & 1 & 0 & 1 & 1 & 1 & 1 \\
Granulocytes in LP & 2 & 2 & 2 & 0 & 3 & 3 & 0 & 2 \\
Microvilli length & $3.4 \pm 0.54$ & - & $4.2 \pm 1.10$ & - & $5.5 \pm 1.3$ & - & $3.1 \pm 0.60$ & - \\
\hline
\end{tabular}

Group 1 = control, Group 2 = low water level treatment; $\mathrm{LM}=$ light microscopy, TEM = transmission electron microscopy, Disint. microvilli = disintegrated microvilli, $\mathrm{OCD}=$ oedema or cell damage, $\mathrm{LP}=$ lamina propria; Microvilli length values $[\mu \mathrm{m}]$ are mean \pm standard deviation; Scores of semi-sections for LM and TEM are based on 10 randomly taken images from each gut segment per treatment; Evaluations were ranked according to Ringø et al. (2007a): $0=$ no observed, $1=10 \mathrm{w}$ (1-3 out of 10 images), 2 = moderate (4-6 out of 10 images), 3 = high ( 7 or more out of 10 images).

Biron and Benfey (1994) showed a short-term increasing of plasma cortisol, haematocrit, and glucose levels on diploid and triploid brook trout, Salvelinus fontinalis (Mitchill, 1814), exposed to 5 min acute handling stress. In contrast, Fridell et al. (2007) reported an increasing of cortisol level during chronic stress response in the hyperoxic group of Atlantic salmon held in freshwater. In the presently reported study, group 2 with decrease of oxygen in water circulation, the cortisol level elevated simultaneously and reduced the erythropoiesis activity compare to control.

Previous studies illustrated blood parameters such as raised haematocrit, lactate level, glucose, osmolality, and plasma cortisol concentration following acute stress in Atlantic salmon (Olsen et al. 2002, Sundh et al. 2009), rainbow trout, Oncorhynchus mykiss (see Olsen et al. 2005); Atlantic cod, Gadus morhua (see Olsen et al. 2008); and European sea bass, Dicentrarchus labrax (see Santos et al. 2010), respectively. The results of the presently report- ed study are in accordance these observations, but the response appeared to be somewhat higher in the control and low water level groups while haematocrit and haemoglobin had lower response in group 2 (Table 4).

Olsen et al. (2008) reported that increasing level of plasma glucose in cod is caused by extended glycogenolysis and gluconeogenesis through the degradation of glycogen, a process that may relate to the prolonged elevated levels of plasma cortisol, which will stimulate these processes. Observations of increased plasma glucose following group one in the presently reported study are in accordance with the results of Barton and Iwama (1991) and Olsen et al. (2002). Although we did observed lower level of glucose in group 2 compare to the control, this finding was marginal and not significantly different.

Our study showed elevation of lactate level after acute post stress in all treatments. A smaller decrease of lactate in group 2 after 65 days of chronic stress compare with 

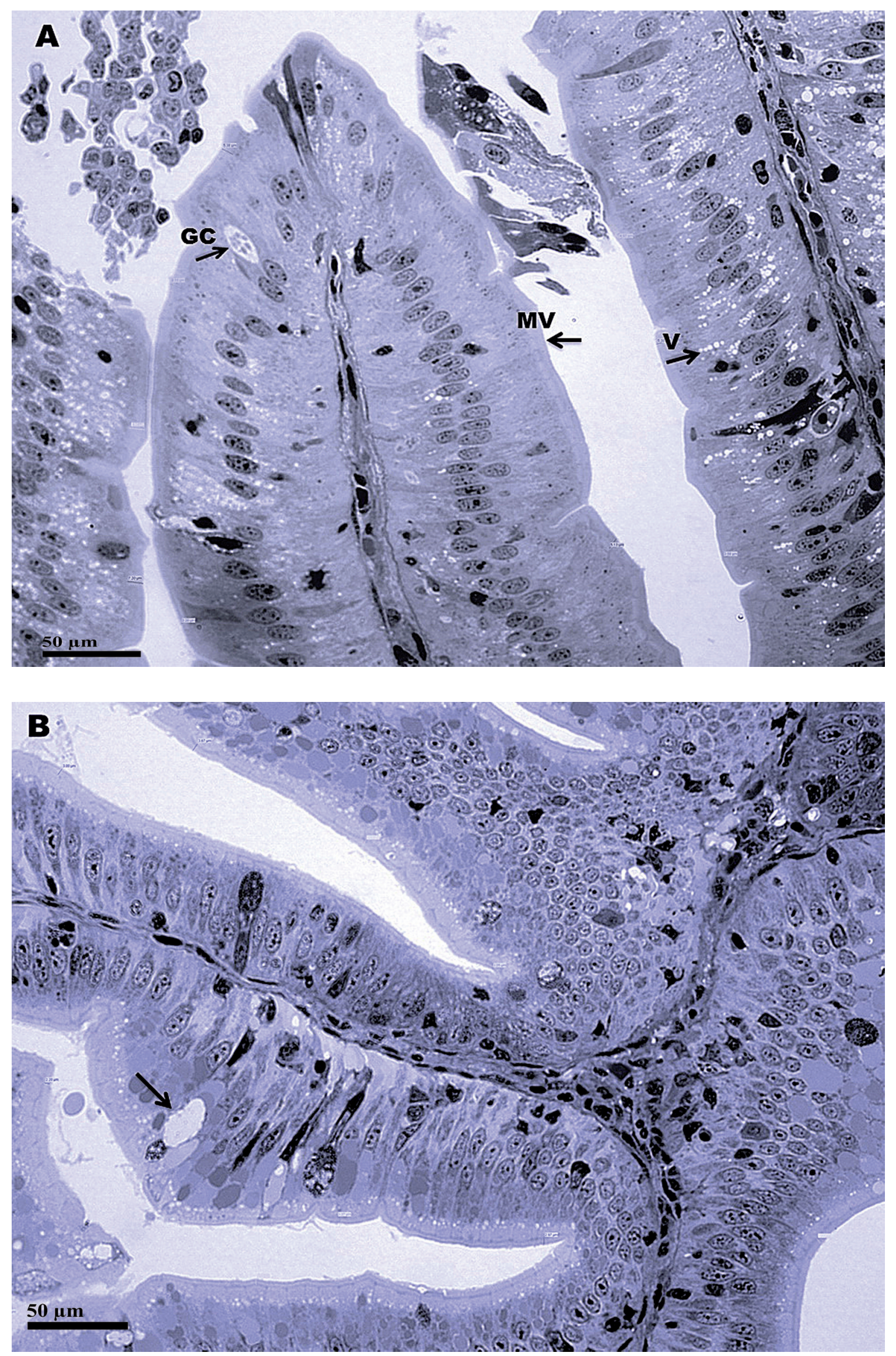

Fig. 1. Light microscopy micrographs of the gastrointestinal tract of Atlantic salmon, Salmo salar, exposed to low water level for 65 days; $\mathbf{A}$ pyloric caeca; $\mathbf{B}$ distal intestine; $\mathrm{MV}=$ microvilli, $\mathrm{GC}=$ goblet cell, $\mathrm{V}=$ vacuoles 


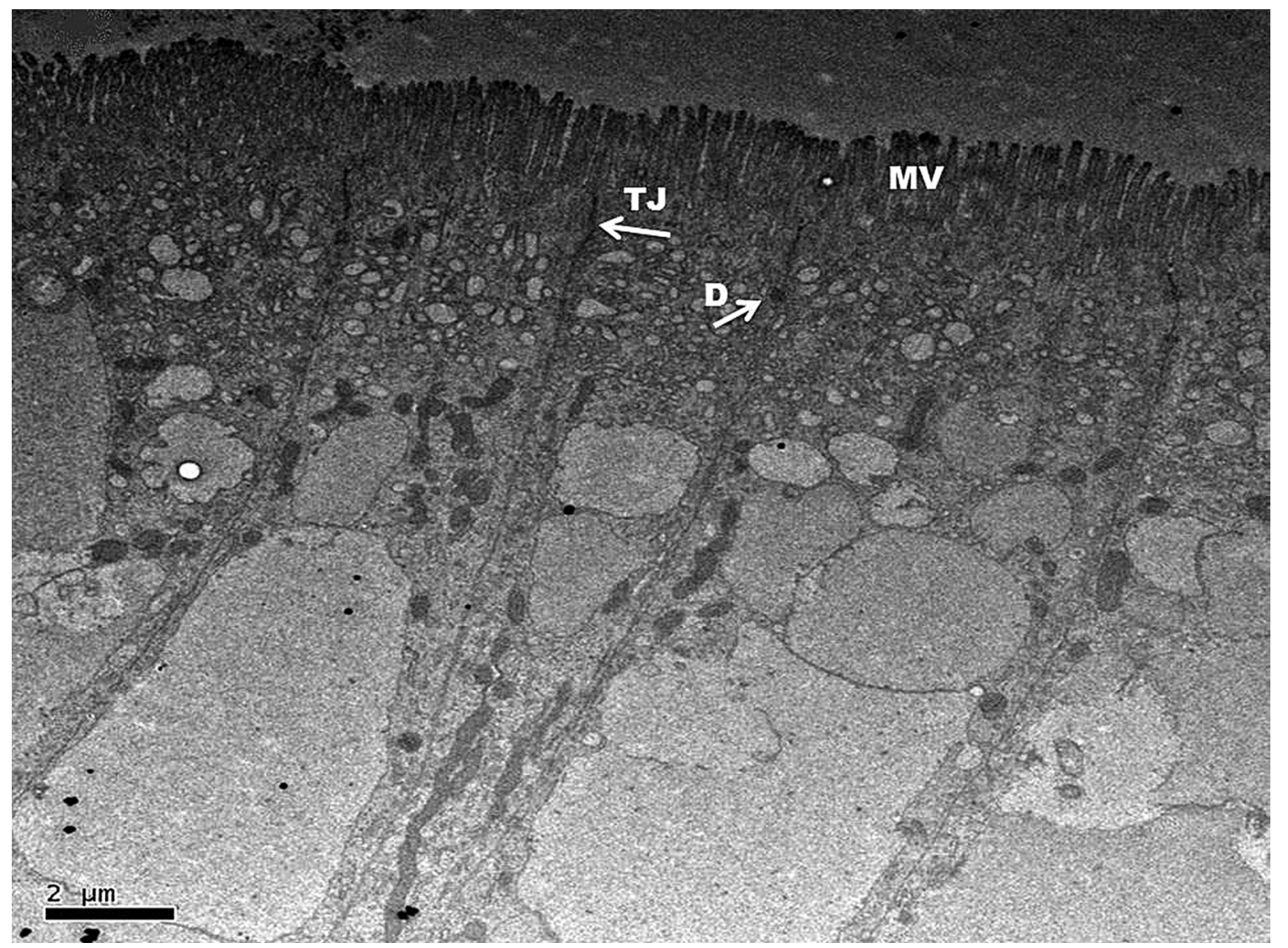

Fig. 2. TEM micrograph of the distal intestine of Atlantic salmon, Salmo salar, exposed to low water level stress for 65 days; $\mathrm{MV}=$ microvilli, $\mathrm{D}=$ desmosome, $\mathrm{TJ}=$ tight junction

acute situation and control treatment was noticed. Lactate levels in group 2 were lower compare with control in acute post stress and might indicate that fish exposed to low water level are better adapted to stress. However, this hypothesis merits further investigations.

Olsen et al. $(2002,2005)$ reported cell damage of Atlantic salmon and rainbow trout intestinal enterocytes during stress. In contrast to these results, no clear effect on cell damage was noticed in the present study, indicating that Atlantic salmon can adapt to chronic stress.

In the presently reported study, no morphological gut changes were observed. Widening of intracellular space was noticed in fish exposed to low water level and vibration stress. These results are in contrast to those published by Olsen et al. $(2002,2005)$, who reported increased intercellular gap in rainbow trout and Atlantic salmon exposed to handling and fasting stress, respectively.

Our study demonstrated that stress did not have any major effect on enterocytes in distal intestine of Atlantic salmon. This observation is in accordance with those reported by Olsen et al. $(2002,2005)$.

The effect of stress responses on gut microbiota and the immune system was investigated in endothermic animals (Kight and Swaddle 2011, González-Rodríguez et al. 2013). In fish, evaluation of the gut microbiota, gut immunology, and challenges studies are important parameters to evaluate in stress experiments. As these tests were not carried out in our study we recommend that these topics are included in future stress studies because the gastrointestinal tract is one of the major infection routes in fish (Ringø et al. 2007a, 2007b).

\section{ACKNOWLEDGMENTS}

We would like to thank Prof. Einar Ringø at University of Tromsø for his valuable helps and advising. We also appreciate the help of Ivar Helge Matre, Grethe Thorsheim, Tone Vågseth, Marita Larsen, Stian Morken, and Lisse Dyrhovden of the Matre Research Station in technical issues and in fish handling. Thanks to Anne Nyhaug and Ingvild Wendelbo of the Molecular and Imaging Center, University of Bergen, Norway for their help on light and electron microscopy evaluation of gut samples.

\section{REFERENCES}

Askarian F., Kousha A. 2009. The influence of photoperiod in farming beluga sturgeon (Huso huso): Evaluation by growth and health parameters in serum. Journal of Fisheries and Aquatic Science 4 (1): 41-49. DOI: 10.3923/jfas.2009.41.49

Barry T.P., Unwin M.J., Malison J.A., Quinn T.P. 2001. Free and total cortisol levels in semelparous and iteroparous chinook salmon. Journal of Fish Biology 59 (6): 1673-1676. DOI: 10.1111/j.1095-8649.2001.tb00230.x

Barton B.A., Iwama G.K. 1991. Physiological changes in fish from stress in aquaculture with emphasis on the response and effects of corticosteroids. Annual Review of Fish Diseases 1: 3-26. DOI: 10.1016/0959-8030(91)90019-G 
Barton B.A., Schreck C.B., Fowler L.G. 1988. Fasting and diet content affect stress-induced changes in plasma glucose and cortisol in juvenile Chinook salmon. The Progressive Fish Culturist 50 (1): 16-22. DOI: 10.1577/1548-8640 (1988)050<0016:FADCAS $>2.3 . C O ; 2$

Biron M., Benfey T.J. 1994. Cortisol, glucose and hematocrit changes during acute stress, cohort sampling, and the diel cycle in diploid and triploid brook trout (Salvelinus fontinalis Mitchill). Fish Physiology and Biochemistry 13 (2): 153-160. DOI: 10.1007/BF00004340

Davidson J., Bebak J., Mazik P. 2009. The effects of aquaculture production noise on the growth, condition factor, feed conversion, and survival of rainbow trout, Oncorhynchus mykiss. Aquaculture 288 (3-4): 337-343. DOI: 10.1016/ j.aquaculture.2008.11.037

De Silva S.S., Anderson T.A. 1995. Fish nutrition in aquaculture. Chapman and Hall, London, UK.

Fast M.D., Hosoya S., Johnson S.C., Luis O.B., Afonso L.O.B. 2008. Cortisol response and immune-related effects of Atlantic salmon (Salmo salar Linnaeus) subjected to shortand long-term stress. Fish and Shellfish Immunology 24 (2): 194-204. DOI: 10.1016/j.fsi.2007.10.009

Fridell F., Gadan K., Sundh H., Taranger G.L., Glette J., Olsen R.E., Sundell K., Evensen Ø. 2007. Effect of hyperoxygenation and low water flow on the primary stress response and susceptibility of Atlantic salmon Salmo salar L. to experimental challenge with IPN virus. Aquaculture 270 (1-4): 23-35. DOI: 10.1016/j.aquaculture.2007.04.081

González-Rodríguez I., Ruiz L., Gueimonde M., Margolles A., Sánchez B. 2013. Factors involved in the colonization and survival of bifidobacteria in the gastrointestinal tract. FEMS Microbiology Letters 340 (1): 1-10. DOI: 10.1111/15746968.12056

Kight C.R., Swaddle J.P. 2011. How and why environmental noise impacts animals: an integrative, mechanistic review. Ecology Letters 14 (10): 1052-1061. DOI: 10.1111/j.14610248.2011.01664.x

Kubilay A., Uluköy G. 2002. The effects of acute stress on rainbow trout (Oncorhynchus mykiss). Turkish Journal of Zoology 26 (2): 249-254.

Martínez-Porchas M., Martínez-Córdova L.R., RamosEnriquez R. 2009. Cortisol and glucose: Reliable indicators of fish stress. Pan-American Journal of Aquatic Sciences 4 (2): 158-178.

Mustafa A., MacKinnon B.M. 1999. Atlantic salmon, Salmo salar L., and Arctic char, Salvelinus alpinus (L.): comparative correlation between iodine-iodide supplementation, thyroid hormone levels, plasma cortisol levels, and infection intensity with the sea louse Caligus elongatus. Canadian Journal of Zoology 77 (7): 1092-1101. DOI: 10.1139/z99-060

Olsen R.E., Sundell K., Hansen T., Hemre G.-I., Myklebust R., Mayhew T.M., Ringø E. 2002. Acute stress alters the intestinal lining of Atlantic salmon, Salmo salar L.: An electron microscopical study. Fish Physiology and Biochemistry 26 (3): 211-221. DOI: 10.1023/A:1026217719534
Olsen R.E., Sundell K., Mayhew T.M., Myklebust R., Ringø E. 2005. Acute stress alters intestinal function of rainbow trout, Oncorhynchus mykiss (Walbaum). Aquaculture 250 (1-2): 480-495. DOI: 10.1016/j.aquaculture.2005.03.014

Olsen R.E., Sundell K., Ringø E., Myklebust R., Hemre G.-I., Hansen T., Karlsen Ø. 2008. Acute stress response in fed and food deprived Atlantic cod Gadus morhua L. Aquaculture 280 (1-4): 232-241. DOI: 10.1016/ j.aquaculture.2008.05.006

Olsen Y.A., Falk K., Reite O.B. 1992. Cortisol and lactate levels in Atlantic salmon Salmo salar developing infectious anaemia (ISA). Disease of Aquatic Organisms 14: 99-104. DOI: $10.3354 /$ dao014099

Ringø E., Myklebust R., Mayhew T.M., Olsen R.E. 2007a. Bacterial translocation and pathogenesis in the digestive tract of larvae and fry. Aquaculture 268 (1-4): 251-264. DOI: $10.1016 / j$.aquaculture.2007.04.047

Ringø E., Salinas I., Olsen R.E., Nyhaug A., Myklebust R., Mayhew T.M. 2007b. Histological changes in intestine of Atlantic salmon (Salmo salar L.) following in vitro exposure to pathogenic and probiotic bacterial strains. Cell and Tissue Research 328 (1): 109-116. DOI: 10.1007/s00441-0060323-0

Santos GA., Schrama J.W., Mamauag R.E.P., Rombout J.H.W.M., Verreth J.A.J. 2010. Chronic stress impairs performance, energy metabolism and welfare indicators in European seabass (Dicentrarchus labrax): The combined effects of fish crowding and water quality deterioration. Aquaculture 299 (1-4): 73-80. DOI: 10.1016/j.aquaculture.2009.11.018

Sundh H., Olsen R.-E., Fridell F., Gadan K., Evensen Ø., Glette J., Taranger G.-L., Myklebust R., Sundell K. 2009. The effect of hyperoxygenation and reduced flow in fresh water and subsequent infectious pancreatic necrosis virus challenge in sea water, on the intestinal barrier integrity in Atlantic salmon, Salmo salar L. Journal of Fish Diseases 32 (8): 687-698. DOI: 10.1111/j.13652761.2009.01047.x

Terhune J.M., Friars G.W., Bailey J.K., O’Flynn F.M. 1990. Noise levels may influence Atlantic salmon smolting rates in tanks. Journal of Fish Biology 37 (1): 185-187. DOI: 10.1111/j.1095-8649.1990.tb05939.x

Vijayan M.M., Aluru N., Leatherland J.F. 2009. Stress response and the role of cortisol. Pp.182-201. In: Leatherland J.F., Woo P.T.K. (eds.) Fish diseases and disorders. Vol. 2. Non-infectious disorders. CABI Press, New York.

Wysocki L.E., Davidson III J.W., Smith M.E., Frankel A.S., Ellison W.T., Mazik P.M., Popper A.N., Bebak J. 2007. Effects of aquaculture production noise on hearing, growth, and disease resistance of rainbow trout Oncorhynchus mykiss. Aquaculture 272 (1-4): 687-697. DOI: 10.1016/ j.aquaculture.2007.07.225

Received: 19 September 2013

Accepted: 24 October 2013

Published electronically: 31 December 2013 